\title{
EXAMINATION OF SATISFACTION RELATED TO INVESTMENTS (2006-2011) ACCOMPLISHED BY THE LOCAL COUNCIL IN ABONY Dr. Brigitta Zsótér Ph.D. ${ }^{1}-$ Anikó Tóth ${ }^{2}$
}

${ }^{1}$ associate professor, University of Szeged, Faculty of Engineering, H-6724 Szeged, Mars ter 7. Hungary

e-mail: zsoterb@mk.u-szeged.hu

${ }^{2}$ graduated student, University of Szeged, Faculty of Engineering, H-6724 Szeged, Mars ter 7. Hungary

\begin{abstract}
In Abony there was a large number of investments between 2006 and 2011 which involved infrastructure. A significant part of them was realized in the framework of EU subsidies and also with the financial support of New Hungary Development Plan - Central-Hungarian Operative Program. During our research we applied the questionnaire method as a result of which we had 608 questionnaire forms filled in. We aimed to examine if there was a change in life quality and the standards of living of the inhabitants due to the investments and also how much they are satisfied with the work of town development of the local council. We can conclude from the research that the investments were not efficient and successful enough. They did not affect most of the inhabitants positively, and the inhabitants think that these investments were not really necessary. There are several reasons for this opinion, for example lack of workplaces, the bad quality roads and lack of entertainment facilities.
\end{abstract}

Keywords: investment, infrastructure, standards of living, resident satisfaction, lack of workplaces

\section{INTRODUCTION}

Abony is located in the south-east part of Pest county in the small region of Cegléd. It can be found $85 \mathrm{kms}$ away from the capital, $320 \mathrm{~km}$ from the western border, while 130-140 $\mathrm{km}$ from the southern, eastern and northern borders. The settlement borders on Jász-NagykunSzolnok county. Its territory is $127.97 \mathrm{~km}^{2}$. Avar findings from the 7-8 centuries have been explored around the town which proves that the area was populated even that time. The town belonged to the fortress of Szolnok in the 13th century. The settlement was first mentioned in a written charter which related to the Weseni family between 1450-1472. The name „Aban" mentioned in the charter probably derives from the old-Hungarian family and clan name with a diminiutive suffix ,-ny” (Balogh 1974) (Györe 2007).

Abony was declared a town in 1993. Since then it has undergone a huge development which is due to investments. A lot of investments was accomplished between 2006-2011 which involved infrastructure. A number of specialist literature treats with regional development (Köszegfalvi, Loydl 2001) (Ehleiter 2007) (Rapkay et al., 2013) (Illés, 2014) and infrastructure (Abonyiné Palotás 2006) (Erlich et. all. 2005). All in all, infrastructe is the whole of services which is the system of institutions ensuring production of material needs and provision of the residents, and these institutions are created as a result of different investments. 
Several investments in the town were realized by means of EU subsidies within the framework of the New Hungary Development Plan Central-Hungarian Operative Program.

The first of the examined investments which was accomplished with a EU subsidy is the enviromental reconstruction of Kossuth square (stage I). The investment was initiated to create a fresh, energetic town to which the appropriate accessibility, the friendly attitude towards investors and residents, modern and foolproof mechanical infrastructure belong. In addition to it, it was necessary to form a healthy, clean, esthetic and ideal living environment, too. Today the stage II of the investment is being realized which involves reconstruction of the park behind the local government, renovation of a busy road in the town centre, installment of surveillance cameras and construction of a new covered market.

The other bigger investment is a project to improve the connections in the inner-city area of Abony in order to realize a more livable settlement. The reason for this investment is that the condition of roads here is well behind either the national or the county average, since only $36,2 \%$ of the roads in Abony are paved, whereas the county average is $50 \%$ and the national average exceeds it very much with its $67 \%$. With the realization of the project five roads in the inner-city area got solid pavement, draining ditches and green surfaces which has a significant impact on the living standards of the residents and also on the successful operation of the local economy. On the basis of the present experiences, the objectives have been realized only partly since bigger companies which could ensure working places for the residents have not settled yet.

An important investment in the town was the construction of the new Kostyán Andor Clinic the purpose of which was to improve the general medical care both for children and adults. Due to the clinic patients can utilize several medical services locally in a comfortable way because they do not have to travel a lot and the waiting time has been reduced, too. Perhaps, it was the most successful investment.

It was followed by another investment considered not so useful for everybody which involves establishment of a new creche in Abony with the name „Kreatív Kópévár”. The subsidy made it possible construct a completely new creche which gives a lot of help for families with young children as the former institutions could not accept more children lacking the necessary place, so one of the parents has to stay at home with the children and this way he/she could not work. The project is considered successful because the institution works with a maximum capacity.

Another inevitable investment was to organize the collection and draining of rainwater in the north-east part of the town. Inner water and rainwater had caused a lot of troubles in Abony. The inner water destroyed more houses so it was a timely investment to drain rainwater and/or inner water from the inner-city area and to construct an infrastructure in the most endangered areas, as there are residential areas in the town which are temporarily covered with water. As a result of the investment the inner water was drained into an artificial lake made on a plot in the property of the local government, next to the town. This way they avoided the danger of more damages.

At the beginning of our research we aimed to assess the level of satisfaction of the population of Abony in connection with the investments and also to examine the changes in the living standards of the residents. We wanted to see if the residents are satisfied with the work of the local government and if there have been any changes in their quality of living due to the investments.

After making some hypothesis we examined their correctness with a questionnaire survey:

1. We assumed that $40 \%$ of the population is not satisfied with the work of the local government and the investments meaning they think that there should be other types of investments because the present ones do not improve their living standards. 
2. We assumed that $50 \%$ of the residents think that these investments are useful for everyone.

3 . We thought that at least $60 \%$ of the answerers have experienced a positive change in their living standards due to the investments (as they see it).

4. We assumed that more than $40 \%$ of the residents think that the local government cannot finance the maintenance of the investments from its own resources.

\section{MATERIALS and METHODS}

The primary research was conducted with the questionnaire survey which is the most common technique of primary research and information collection. Its purpose is to collect information from people and from a given group or groups of population.

The questionnaire is the most frequent method of information collection in Gallup poll. The Gallup poll works with relatively large samples and asks similar questions. The questionnaire method is directed to the many and not to the individual that is why the essence of the method is that the collected data can be statistically processed and analyzed (Horváth 2004).

Compiling our questionnaire we applied the basic rules:

- One of the most important steps is to call the attention to the fact that it will be completed without asking the name and address, so it is anonymous.

- The questions should not influence the answer.

- The question should be comprehensible for everyone the possible terminology should be explained.

- The answers should be appropriate for further process (Horváth 2004).

The questionnaire consists of 19 questions the larger part of which focuses on the investments and on the level of satisfaction related to them, besides, what effects the investments have on the life of the answerer and his/her environment. At the end of the questionnaire there is a demographic section.

There were some closed questions which have different types:

- with two options: The answerer can choose from two options.

- multiple options: The answerer can choose from more options.

- selective: The answerer can choose from the given options but also he/she has to opportunity to express his/her own opinion.

Besides closed questions we applied open questions as well where the answerer could write his/her own opinion. We used a qualifying scale to assess the changes in the living standards before and after the investments (Végné 2006).

After compiling the questionnaire we had a piloting survey to see if the questions are in a logical order and if they are comprehensible for everyone (Kotler 1999).

The survey took place between 1 June and 31 August, 2012. We found assessable 608 of the 611 completed questionnaires.

\section{RESULTS and DISCUSSION}

After processing the questionnaires we got the following results in the order of the hypothesis:

1. We assumed that $40 \%$ of the population is not satisfied with the work of the local government and the investments meaning they think that there should be other types of investments because the present ones do not improve their living standards. As a result of our research we can say that this hypothesis has been proved since $39 \%$ 
of the answerers gave mark 1 or 2 to the work of the local government. However, it also means that the bigger part is satisfied.

2. We assumed that $50 \%$ of the residents think that these investments are useful for everyone. This hypothesis has to be rejected since only $34 \%$ of the answerers thought that the investments would be useful for everyone. $25 \%$ could not judge it and $41 \%$ thought there would be some people the investments would not have any effect on.

3. We thought that at least $60 \%$ of the answerers have experienced a positive change in their living standards due to the investments (as they see it). This hypothesis has to be rejected again as only $22 \%$ experienced a certain change while the others did not see either a positive or a negative change. Altogether, only 102 people $(16 \%)$ of the answerers felt a positive change in the living standards due to the investments.

4. We assumed that more than $40 \%$ of the residents think that the local government cannot finance the maintenance of the investments from its own resources. The research supported this assumption. $50 \%$ of the answerers thought the same.

All in all, it can be said the hypothesis 1 and 4 have been proved, while 2 and 3 have been rejected which means that the investments did not bring the expected success. They did not have a positive impact on the lives of many people, besides, the residents think that they were not really necessary to carry out.

At the end of the questionnaire we asked the people to suggest what investments would help the further development of the town, which are the ones that could make it more attractive and more livable. Summing up them: most of them need a covered swimming pool which would resolve the problem of winter swimming for children, adults and the elderly. It would be a good chance for relaxation which the residents lack. A lot of people mentioned the construction of a culture and leisure centre where the younger generation could spend their time in a useful way in an esthetic environment under the surveillance of adults for a modest price. The touristic attraction of Abony should be increased by renovating and extending the village museum. For most of the residents investments which create new workplaces would be the most important ones as the level of unemployment is high in the town. More streets and roads should be freed from dust. If there is the opportunity, the town should organize more community programs because the residents really need them. More cameras should be installed in smaller streets, too, to prevent crime.

\section{REFERENCES}

Abonyiné Palotás J. (2006): Az infrastruktúra elemeinek változó szerepe a területi fejlődésben Magyarországon. SZTE Gazdaság- és Társadalomföldrajz Tanszék, Szeged, pp. 30-35.

Balogh S. (1974): Kinizsi és Abony - adatok Abony megye község 1450-1550 évek közötti történetéhez. Ceglédi Füzetek 21. szám, pp. 10- 64.

Ehleiter J. (2007) A településirányítás elmélete és gyakorlata. HVG-Orac, Budapest.

Ehrlich É. - Szigetvári T. - Székely Grné. - Mihályi P. - Polónyi I. - Kerekes S.- Vavró I.(2005): Az infrastruktúra fejlettsége Magyarországon 1990-2002. Sík Kiadó, Budapest, pp. 9-21.

Györe P (2007): Út menti keresztek Abonyban. Abonyi Lajos Múzeumi Alapítvány, Abony, p. 10.

Horváth Gy. (2004): A kérdőíves módszer. Müszaki Könyvkiadó, Budapest, pp. 5-54. 
Illés S. (2014): Local economic development and paternalism in Hungary. Paripex Indian Journal of Research, vol. 4. no. 2. pp. 147-150.

Kotler, Philip (1999): Kotler on Marketing. How to create, win and dominate Markets, The Free Press, New York.

Kőszegfalvi Gy. - Loydl T. (2001): Településfejlesztés. ELTE Eötvös Kiadó Kft, Budapest.

Rapkay B. - Illés S. - Stárics R. (2013): A helyi gazdaságfejlesztés egyes gondolati elözményei és következményei. Földrajzi Közlemények, 137. évf. 1. sz. pp. 28-39.

Végné F. A. (2006) A marketing alapjai. Műszaki Kiadó, Budapest 208-218.pp. 